\title{
SUFISM IN THE PERSPECTIVE OF IBN KHALDUN AND IBN TAIMIYAH: A COMPARATIVE STUDY
}

\author{
Rahmat Effendi \\ Universitas Islam Negeri (UIN) Sunan Kalijaga Yogyakarta, rahmateffendiyessa97@gmail.com
}

(02021 by the authors. Submitted for possible open access publication under the terms and conditions
of the Creative Commons Attribution-ShareAlike 4.0 International License (CC-BY-SA)
license (https://creativecommons.org/licenses/by-sa/4.0/)
do) DOI: http://dx.doi.org/10.30983/fuaduna.v5i1.4098

\begin{abstract}
The discourse of Sufism in contemporary period has been widely practiced. Even so, Sufism which is understood by Muslims there is disorientation in understanding it, especially as a result of the influence of Ibn Taimiyah and Ibn Khaldun. With a theological-rationalist approach, both have criticized and reconstructed Sufism teachings at a level that is acceptable to Muslims. Both also explain the meaning of Sufism as far as they can reach. This article examines the comparative discourse on the concept of Sufism between Ibn Taimiyah and Ibn Khaldun. This research is library research using descriptive-analytical and comparative methods. Their thoughts on Sufism were dissected in depth which was then compared to find common ground for similarities and differences. The Sufism paradigm put forward by Ibn Taimiyah and Ibn Khaldun provides an overview at the theoretical and practical levels that can be explained rationally. That way Muslims are not polarized in understanding Sufism which seems to love the afterlife and leave the world. Finally, this research shows that Sufism can be practiced by Muslims in their respective capacities.

Keywords: Akhlaqi Sufism; Falsafi Sufism; Ibn Taimiyah; Ibn Khaldun; Comparative Study.
\end{abstract}

\begin{abstract}
Abstrak
Wacana tasawuf pada masa kontemporer saat ini telah marak dilakukan. Meskipun begitu tasawnf yang dipahami oleh umat Islam terdapat disorientasi dalam memahaminy a, terutama akibat dari pengaruh Ibn Taimiyah dan Ibn Khaldun. Dengan pendekatan teologis-rasionalis keduanya telah melakukan kritik dan rekonstruksi ajaran tasawuf dalam tataran yang dapat diterima oleh umat Islam. Keduanya juga menjelaskan makna tasawnf sejauh yang dapat mereka jangkau. Artikel ini mengkaji diskursus perbandingan konsep tasawnf antara Ibn Taimiyah dan Ibn Khaldun. Penelitian ini adalah studi pustaka (library research) dengan menggunakan metode deskriptif-analitis dan komparasi. Pemikiran keduanya atas tasawuf dibedah secara dalam yang kemudian dikomparasikan guna menemukan titik temu persamaan dan perbedaannya. Paradigma tasawuf yang dikemukakan oleh Ibn Taimiyah dan Ibn Khaldun memberikan gambaran dalam tataran teoritis dan praktis yang dapat dijelaskan secara rasional. Dengan begitu umat Islam tidak terpolarisasi dalam memahami tasawnf yang terkesan cinta akbirat dan meninggalkan dunia. Akbirnya penelitian ini menunjuk.kan bahwa tasawnf pada dasamya dapat dipraktikkan oleh umat Islam dalam kapasitasnya masing-masing.
\end{abstract}

Kata kunci: Tasawuf Akblaqi; Tasawuf Falsafi; Ibn Taimiyab; Ibn Khaldun; Studi Perbandingan. 


\section{INTRODUCTION}

Ibn Taimiyah ${ }^{1}$ and Ibn Khaldun ${ }^{2}$ are two figures of medieval Islamic scholar who are famous up to this day. ${ }^{3}$ Their fame can be seen from works and thoughts that are used as sources and references in Islamic studies. Both have the same commitment to evaluate Islamic ideas that developed in the past. One of the ideas targeted by the two figures is Sufism. The second shot is important because Sufism in the Middle Ages was very influential in the religious life of society. On the other hand, Sufism is closely related to other dimensions of life such as politics and power in Islam. ${ }^{4}$ Sufism as a practice of life, theologically legitimized in the Qur'an and hadith. ${ }^{5}$ This is what causes the need for reconstruction efforts on Sufism by both of them. The reconstruction initiated by the two started from their understanding of Sufism in general. Then proceed to a deeper level, causing criticism by both. The criticisms raised by both are harsh and sharp. ${ }^{6}$ This is because both disciplines are

${ }^{1}$ The real name of Ibn Taimiyah is Abū 'Abbās Taqī al-Dīn Ahmad bin 'Abd al-Salām bin 'Abdullāh bin Taimiyah al-Harrānī. He was born in Harrān pada 10 Rabi' al-Awwal $661 \mathrm{H} / 22$ January $1263 \mathrm{M}$ and died on $22 \mathrm{Dzu}$ alQa'idah 728 H/26 September 1328. See Sa'id 'Abd al-' Azhim, Manhaj Syaikh al-Islam Ibn Taimiyah: al-Tajdidiy alSalafiy wa Da'wat al-Ishlabiyyat (Iskandariyah: Dar al-Iman).

2 The real name of Ibn Khaldūn is Abū Zaid 'Abd al-Rahmān bin Muhammad bin Khaldūn al-Hadhramī. He was born in Tunisia pada 1 Ramadhan 732 H/27 Mei 1332 $\mathrm{M}$ and died in Kairo on 26 Ramadhan $808 \mathrm{H} / 19$ Maret 1406 M. See Kamil Hammud, Dirasat Fi Tarikh Al-Falsafat Al-'Arabiyyat, Cet. 1. (Beirut: Dar al-Fikr al-Libnani, 1990).

Press, 2015).

${ }^{3}$ H. Zuhri, Nalar Kalam Pertengahan (Yogyakarta: FA

4 Fazlur Rahman explained clearly how the development of Sufism which started from the power of spirituality to become a temporal force that occupies the seat of power and politics of Muslims. As a practice of life, Sufism which begins with the concern of each individual, becomes a collective routine which then penetrates into the temporal world through the influence of Sufism teachings on the authorities. Through the hands of the ruler, Sufism can stand upright as part of the ruler's policy and dominate the territory of power. See Fazlur Rahman, Islam (Chicago and London: University of Chicago Press, 2020).

5 Islamic Art \& Spirituality (New York: State University of New York Press, 1987).

6 The reconstruction and criticism initiated by Ibn Taimiyah and Ibn Khaldun in this study are centered on diverse and use different approaches. This is so that Muslims do not misunderstand and practice Sufism in life.

The study of Ibn Taimiyah and Ibn Khaldun is also very much in demand by Muslim and Western intellectuals, both classical and modern, even today. According to Nurcholis Madjid, Ibn Taimiyah's Sufism thought was in the form of his views on Sufism, both theoretical and practical in the body of Muslims. For Nurcholis Madjid, Ibn Taimiyah supported the concept of Sufism in part and rejected the other part. Abdul Mun'im Kholil stated that Ibn Taimiyah was an anti-Sufi who with his methodology rejected Sufism understandings through three doors, namely tarekat, knowledge of inspiration, and zhahir-bathin dualism. As for the thought of Ibn Khaldun's Sufism, Abdul Kadir Riyadi assessed that it was just an explanation of Sufism as part of the life of Muslims. According to him, Ibn Khaldun did not enter the world of Sufism to become a Sufi. But Ibn Khaldun is only an observer of science in Islam and in the context of systematizing knowledge. ${ }^{7}$ Stephen Casewit also saw that Ibn Khaldun was a very rational person, so he did not fit to be categorized as a Sufi, but as a social expert. ${ }^{8}$

Observing previous studies, the author found a tendency to confront the thoughts of the two figures above. The two seem to have no connection or similarity at all. Ibn Taimiyah is positioned as an anti-Sufi. Meanwhile, Ibn Khaldun is positioned as a rationalist-socialist. So they have no relationship with Sufism. In fact, if

their respective works, namely Figh al-Tashawwuf by Ibn Taimiyah and Muqaddimah by Ibn Khaldn. It would be wrong to say that both of them were only criticizing Sufism by not providing a way out. Therefore, it is important for the author to convey as an apology that both of them helped reconstruct Sufism as an understanding among Muslim.

7 Abdul Kadir Riyadi, 'Tasawuf Antara Penafsiran Normatif Dan Sosiologis Dalam Pemikiran Ibn Khald $\AA$ «n', ISLAMICA: Jurnal Studi Keislaman, 12.1 (2017), 80-166 <https://doi.org/10.15642/islamica.2017.12.1.80-166>.

8 Stephen Casewit, 'The Mystical Side of the Muqaddimah: Ibn Khaldun's View of Sufism', Islamic Quarterly, 29.3 (1985). 
examined further, the two figures are both in the middle period, namely after the collapse of Islamic civilization in the 13th century. Even though Ibn Taimiyah and Ibn Khaldun are almost close in age and time, the distance and place that separates them so that the thoughts of the two figures do not intersect. After further research, the thoughts of the two figures have a relationship and a common point of view in understanding Sufism. In addition, there are also different views based on the basis and method of thinking. The equation is in the form of a general understanding of Sufism as part of reality that cannot be separated from the body of Muslims. The difference is due to the point of view of these two figures who have different scientific concerns. Academics see that both have a big role in building the Sufism paradigm, both reconstructive and critical. ${ }^{9}$ So don't be surprised if they become a reference in understanding Sufism for academics and the Ummah.

This paper will dissect and compare ideas about the meaning, elements, dimensions and practices of Sufism from the two figures. What and how to address the thinking paradigm of Ibn Taimiyah and Ibn Khaldun on Sufism is the focus of this research. The wrong understanding of Sufism in society needs to be straightened out and justified. Then the view of Sufism by Ibn Khaldun and Ibn Taimiyah is not only positioned as a comparison material, but as a basis for Muslims in understanding Sufism that is more comprehensive and integral. A comprehensive understanding of Sufism will lead Muslims to the point where differences show diversity, not differences as threats and divisions. On the other hand, through this research, the writer wants to state that Sufism as judged by people who claim to be anti-Sufism or anti-Sufism is wrong and inappropriate to say that it is infidel to polytheist.

${ }^{9}$ Ahmad Syafi'i Ma'arif, Ibn Khaldun dalam Pandangan Penulis Barat dan Timur (Yogyakarta: Gema Insani, 1996); Abu Bakar Aceh, Pengantar Sejarah Sufi \& Tasawwuf (Solo: Ramadhani, 1994).
Rather, Sufism is a practice of life that anyone can do and that is also recommended in Islam.

This research is a qualitative research based on library research. A discovery of the thoughts of Ibn Taimiyah and Ibn Khaldun through their works and other works that discuss Sufism. The method used is descriptive-analytical and comparative. Sufism in its concept accepted and supported by the two figures has similarities and differences, both in terms of definition, approach, study, and practice. Mainly the views of the two figures on the concept of advanced Sufism, both of which responded with contra. In this way, this research will reveal the views of the two figures to what extent they accept and reject it. Then draw a common thread from the controversy in order to solve the academic and social problems that arise.

The primary source in this research is Ibn Taimiyah and Ibn Khaldun's work, which discusses Sufism's problem. The work of Ibn Taimiyah that discusses the problem of Sufism is Fiqh al-Tashawwuf. The work of Ibn Khaldun which also discusses Sufism is in his magnum opus, namely Muqaddimah. Secondary sources in this study are the works of other thinkers who discuss the concept of Sufism from these two figures and Sufism in general, both in the form of journal articles, research reports, text books, and other relevant sources.

This paper will compare the Sufism thoughts of the two figures above. The method used in this research is descriptive-analytical and comparative. This descriptive-analytical method will explain how Ibn Taimiyah and Ibn Khaldun on Sufism comprehensively and integrally will then be studied critically. From this explanation, the thoughts of the two figures will be compared, both in terms of similarities and differences, which then draws the red thread for the controversy that arises from their thoughts which cause ambiguity among the people of Sufism. So that in the end it can be revealed where the gap left by the two and it is clear that Sufism from the 
basic to advanced levels can be accepted and practiced in life.

The discussion in this paper begins with an introduction which leads to the gap in the research. Then proceed with an overview of Sufism that has a relationship with this research. The definition of Sufism in etymology and terminology needs to be explained in order to get a comprehensive understanding of Sufism. The development of Sufism in practice needs to be conveyed which shows is a shift in the dimensions of Sufism from practice to theory. Also presented are several terms in theoretical Sufism that are debated in this study. Next is the research method as an operating tool in this study. As content, it begins with an explanation of the concept of Sufism by Ibn Taimiyah and Ibn Khaldun. After that, draw a common thread over the meeting point of the similarities and differences of the two figures. Finally, the conclusion is the hope of this research on academic and social conditions.

The research on the concept of Sufism by Ibn Taimiyah and Ibn Khaldun is basically a critique of Sufism itself. Ibn Taimiyah criticized the scientific side of Sufism which for him came back to the Islamic world. In addition, there is a need for reconstruction efforts (reconstruction) according to Ibn Taimiyah in building an Islamic Sufism paradigm. Meanwhile, Ibn Khaldun as a scientist, in the Muqaddimah explained in the context of systematizing knowledge. Both provide views on Sufism as both a science and a practice of life. This is aimed at Muslims, especially in order to know the treasures of science in Islam.

\section{A GLIMPSE OF SUFISM}

Sufism, known in the Islamic world, became an established discipline after the 3rd century Hijriyah or 9th century AD. ${ }^{10}$ At least in the middle of the 4th century Hijriyah or the 8th AD, it became the starting point for Sufism to be

\footnotetext{
${ }^{10}$ Haidar Bagir, Buku Saku Tasawuf (Mizan, 2006).
}

introduced in the Islamic world. This makes Sufism a new discipline that was born later in Islam. At this time great Sufism thinkers were born such as al-Bishr, Abu Hasan al-Hallāj, Ibn 'Arab and al-Jilli. They all introduced how their Sufism thought based on their inner experiences. That inner experience is conveyed symbolically through various revelations. Sufism became an important scientific discipline that also gave a pattern in the intellectual treasures of Islam, both in classical, medieval, and modern times. ${ }^{11}$

In terms of language, the word Sufism does not have original syllables in Arabic. The word Sufism is an absorption and lexical change of words from several words that linguists mention them. At least the word change is taken from the word tashawwafa-yatashawwafu-tashawmufan which means clean, pure, and clear. ${ }^{12}$ The word Sufism as most mentioned comes from the word suf which means wool. The wool here is the clothes of the ancient people who were simple and rough as a form of their modesty and modesty. ${ }^{13}$ There is also the word abl al-shuffah which means the porch of the mosque. Because at the time of the Prophet SAW, friends who did not have a home and were classified as poor chose to live in one of the porches of the Prophet's mosque. ${ }^{14}$ Then from the word shuff which means rows in prayer. Because a Sufi as exemplified by a friend always targets the front row in prayer. Then from the absorption of the word sophos which means wisdom. This word has been adapted from Greek to Arabic which means wisdom. A Sufi is a wise person. ${ }^{15}$

11 Sirajuddin Zar, 'Relevansi Tasawuf di Era Modern', Mumtaz: Jurnal Studi Al-Quran dan Keislaman, 2.1 (2018), 121-32 (pp. 121-22) <https://doi.org/10.36671/mumtaz.v2i1.22>.

12 Abuddin Nata, Studi Islam Komprehensif Jakarta: Prenada Media, 2015).

13 Harun Nasution, Islam Ditinjan dari Berbagai Aspeknya (Jakarta: Universitas Indonesia Press, 2015), II.

14 Alexander Knysh, Islamic Mysticism: A Short History (Leiden and Boston: Brill, 2010).

${ }^{15}$ Henry Corbin, History of Islamic Philosophy (London and New York: Routledge, 2014). 
Sufism has been defined in terms by several experts. Al-Ghazālī defines Sufism as the wisdom and wisdom of knowing Allah SWT in its way, namely the path of earnestness, abandoning despicable traits, and filling oneself with divine attributes. ${ }^{16}$ According to al-Junaidi, Sufism is self-purification from various bad qualities and weak traits, staying away from all basic or natural human actions, and staying away from lust. ${ }^{17}$ Meanwhile, according to al-Syadzili tasawuf is the practice of worship through exercises to get closer to Allah SWT. ${ }^{18}$ Seyyed Hossein Nasr views Sufism as a world view of various world problems by using the wisdom of Sufism. Because by using the esoteric side of Islam, life's problems will be resolved. ${ }^{19}$ Seeing the many definitions given by some Sufism experts, then at least Sufism can be interpreted as a way or way for someone to get closer to Allah SW'T to have the closest relationship without any limitations (bijab) by passing certain procedures.

In the world of Sufism, a person who practices Sufism is known as a Sufi. Sufis practice ascetic life through various maqamāt and ahwàl. Maqamät is the plural of maqām which means place, stage, station. ${ }^{20} \mathrm{~A}$ person who carries out Sufism must go through various stages in order to reach a degree where there is no boundary (bijab) between him and God. This maqamät varies, starting from repentance, zubüd, gratitude, qana'ah, and others. While abwäl, the plural of häl is a state. The meaning in Sufism is the state feeling by the Sufi in every achievement of maqaim

16 'Isa 'Abdullah 'Ali, 'Al-Falsafat Wa Al-Tashawwuf Fi Fikr Hujjat Al-Islam Abi Hamid Al-Ghazali', DINIKA: Academic Journal of Islamic Studies, 2.2 (2017), 247 <https://doi.org/10.22515/dinika.v2i2.826>.

17 Eep Sofwana Nurdin, Pengantar Ilmu Tasawnf (Bandung: Aslan Grafika Solution, 2020).

18 Kautsar Azhari Noer, 'Mukadimah', in Warisan Agung Tasawnf: Mengenal Karya Besar Para Sufi (Jakarta: Sadra Press, 2015).

19 Seyyed Hossein Nasr, Tasawuf Dulu dan Sekarang, judul asli Living Sufism, terj. Abdul Hadi WM. (Yogyakarta: IRCiSoD, 2020).

${ }^{20}$ Muhammad Afiq Zahara, Pintu Tasawuf: Eksplorasi Singkat Terhadap Terminal-terminal Sufi (Maqam Sufi) (Yogyakarta: Penerbit Pacu Media, 2017). which itself is a gift from God. ${ }^{21}$ There are many things that a Sufi, among them feel are fan $\bar{a}^{\prime}$ and $b a q \bar{a}^{\prime} .{ }^{22}$ These two terms, both maqamät and ahwäl, must be done and felt by a Sufi in his spiritual journey seriously (mujähadah). The difference is, maqamät must be achieved by the Sufi himself, while abwäl is a gift from God. ${ }^{23}$

During its development, Sufism from a practical orientation changed to a theoretical orientation. This cannot be denied because Islam in its spread intersects with other cultures, such as Greek Hellenism, Egyptian Culture (Egypt), and Farsi (Persian). This causes cultural acculturation to occur which results in a paradigm shift in the normality of the concept of Sufism. This also led to the birth of Akblaqi Sufism and philosophical Sufism. Because basically Akblaqi Sufism is inherent in every individual Muslim. As for what left the problem among the people and the Sufis themselves, it was philosophical Sufism. Philosophical Sufism is what intersects with various thoughts so that it gives birth to various existing Sufism ideas, such as ittihäd, bulul, nur Mubammad, and wabdat al-wujud. ${ }^{24}$ Similarities and differences of opinion among Sufis have existed for a long time as different forms of thought and practice in life. It is not strange if strange words (shathahat) come out in response to personal experience. $^{25}$ So Sufism has an extraordinary intellectual treasure besides its life practice.

Observing the rise of ascetic statements that are out of the ordinary, led to Sufism recieving criticism from various parties. From

21 Said Aqil Siroj, Tasawuf Sebagai Kritik Sosial: Mengedepankan Islam Sebagai Inspirasi, Bukan Aspirasi (Bandung: Mizan Pustaka, 2006).

22 Sokhi Huda, Tasawnf Kultural: Fenomena Shalawat Wahidiyah (Yogyakarta: LKiS Yogyakarta, 2008).

${ }^{23}$ Syamsun Ni'am, 'The Debate of Orthodox Sufism and Philosophical Sufism: The Study of Maqāmāt in the Sirāj Al-Ṭālib̄̄n of Shaykh Iḥsān Jampes', Al-Jami'ah: Journal of Islamic Studies, 58.1 (2020), 1-34 (pp. 5-7) <https://doi.org/10.14421/ajis.2020.581.1-34>.

${ }^{24}$ Lalu Muhammad Nurul Wathoni, Akblak Tasawn: Menyelami Kesucian Diri (Lombok: Forum Pemuda Aswaja, 2020).

25 Ibn Taimiyah, Istiqamah: Akidah, Ibadah, \& Tasawuf(Jakarta: Pustaka Al-Kautsar, 2016). 
within Islam itself, Sufism has received criticism from exoteric groups represented by fuqaba $\bar{a}^{\prime}$ or scripturalists who claim to be religious authorities. This group made variations in worship under the pretext of making variations in worship to cause shirk, disbelief, and apostasy. ${ }^{26}$ Then, with the reality of the existing power, the Sufis were removed from the Islamic intellectual scene. As happened to Mansur al-Hallāj ${ }^{27}$ and alSuhrawardī al-Maqtul. ${ }^{28}$ Their strange words caused them to die at the hands of the ruler. This causes Sufism to be graded until it loses its fans. Even the Islamic conservative-separatists firmly reject the concept of Sufism in Islam. Islamic society has a dilemma in understanding Sufism to stay away from Sufism. Therefore, many Islamic thinkers and scholars have contributed to this problem. At least in this study by Ibn Taimiyah and Ibn Khaldun who also took part in the stage of Islamic intellectuals. Both of them contribute to Muslims in understanding Sufism as far as they see it.

The issues above have become a hot topic in the study of Sufism since ancient times until now. Instead of claiming that Sufism or mysticism was abandoned in Islam which,

26 Wahiduddin Khan, Kritik Terhadap Ilmu Fiqih Tasawuf Dan Ilmu Kalam, judul asli Tajdid 'Ulum al-Din, terj. Moh. Nurhakim (Jakarta: Gema Insani Press, 1994).

${ }^{27}$ Manshur al-Hallāj suffered a tragic death because of his strange arguments which greatly affected power. as an intelligent person and has extensive Islamic knowledge, he with all the strange statements must be in prison before meeting his death. This was because of his closeness to the royal family at that time which made social jealousy occur from exoteric circles ('ulama' as legal authorities or fuqahā'). This jealousy makes and its arguments must be silenced. Then all forms of spiritual-esoteric activities are prohibited in the name of power. Plus he was accused of being a Shia follower. Seyyed Hossein Nasr, 'Sufism and Spirituality in Persia', in Islamic Spirituality: Manifestations (New York: The Crossroad Publishing Company, 1997); Knysh.

${ }^{28}$ Suhrawardī al-Maqtūl also suffered the tragic fate of having to accept his death by hanging. Even with the illumination style, the strange statements made by him make the exoteric hate him very much. Plus the envy because al-Suhrawardī had a close relationship with prince al-Malik al-Zhahir son of Saladin al-Ayyūbī. Lihat Annemarie Schimmel, Mystical Dimensions of Islam (Chapel Hill: The University of North Carolina Press, 1975), pp. 259-60. because of attacks from various parties, could not be justified. Even Sufism grew alive with these attacks. It is proven in his area of study in philosophical Sufism, which is not only theoretical-ascetic. Instead, it also led to the study of metaphysics, cosmology, until it succeeded in becoming the hegemony of power politics. ${ }^{29}$ In the next phase of development, Sufism became an institution that was practiced in the tariqat community. This tariqat is then becomes sporadic and more existent in the world than Sufism itself at the theoretical level. Many tariqat schools originally started from the development of Sufism teachings into a large institution in the practice of Islamic teachings. ${ }^{30}$

\section{SUFISM CONCEPT BY IBN TAIMIYAH DAN IBN KHALDUN}

Sufism discourse in the criticism of Ibn Taimiyah and Ibn Khaldun cannot be separated from Sufism itself. Ibn Taimiyah explains how Sufism is in religious practice that lives in Islamic society. Likewise, Ibn Khaldun framed it in the systematization of knowledge in Islam. However, in reality it is necessary to criticize Sufism both in practical and theoretical terms. Because there is no doubt that the idea of Sufism also contains contradictory values for Islamic society. This can be tolerated for those who are anti-Sufism and the opposite of Sufism supporters. There needs to be improvements while straightening out the teachings of Sufism which allegedly came from the Prophet SAW. This discourse begins with a discussion of the meaning of Sufism, the elements of Sufism, the dimensions of Sufism, to the practice of Sufism.

Sufism for Ibn Taimiyah did not come from the original Arabic. As mentioned by several previous experts, both from the words ahl alshuffah, shuf, and shaf, all of them are wrong and

${ }^{29}$ Haidar Bagir, Mengenal Tasamuf (Jakarta: Noura Books, 2019).

30 Hassan Marzouqi, Tariqa Islam: Layers of Authentication (Doha: Arab Center for Research \& Policy Studies, 2013), pp. 35-36. 
wrong. In this context it is not sourced from Islam, especially in Arabic. Ibn Taimiyah assumes the meaning of the word Sufism from the word shuf, which means wool as the basic material for clothing worn by the companions at that time. ${ }^{31}$ As the terminology used, that shuf which means wool as a symbol of the simplicity of a servant in front of his Lord. In line with Ibn Taimiyah, according to Ibn Khaldun who quoted al-Qusyairī, that the word tasawuf is an invented word from the word shuf. Thus Sufis are simple people who thus show their opposition to the luxuries of this world, so that they are oriented only to the hereafter. Through this initial definition, the Sufism paradigm is built in Islamic society on various ascetic and individualistic life practices.

In a further definition, Ibn Taimiyah considers that the word Sufism as a form of a way of life that is zuhüd and worship solely because of Allah SWT, has a theological basis as its legitimacy. ${ }^{32}$ In term of al-shiddiqin as a form of image of the Sufis who are always on the right path (tariq al-baqq). This is an emphasis that the shiddiqin are those who are experts in asceticism and worship ('abid). What they seek is nothing but the hereafter. ${ }^{33}$ Likewise, as a seeker of the right path which is legitimized in the Qur'an. ${ }^{34}$ The dimensions in Sufism mentioned by several Sufism figures such as al-Qusyairī, Abu Nasr alSarrāj, and al-Kalabazī, are the same as those mentioned in the Qur'an and al-Sunnah. The terminology they make basically takes from these two Islamic sources and expands their meaning. Meanwhile, Ibn Khaldun translates as conveyed by the Sufis of his time as spiritual exercises that lead a person to certain circumstances which become a habit that is ingrained in him. The term maqām as a stop (station) can also be interpreted

31 Ibn Taimiyah, Fiqh Al-Tashammuf (Beirūt: Dar alFikr al-'Arabi, 1993), pp. 11-12.

${ }^{32}$ QS. Al-Nisā' [4]: 59.

${ }_{33}$ Taimiyah, Fiqh Al-Tashannuf, p. 18.

34 QS. Al-Fātihah [1]: 6-7. as not a form of worship, but a character that affects the soul and appears in life. ${ }^{35}$

In terms of the basis of Sufism as legitimacy in Islam, Ibn Taimiyah and Ibn Khaldun also provide views. Ibn Taimiyah emphasized the importance of the theological foundation. Because a science in Islam must rely on the Qur'an and hadith. Both in terms of definition, practice, and the teachings of Sufism must be based on the verses of the Qur'an. Like the way of life that is zubud, grateful, taubah, qana' $\bar{a}^{\prime}$, and so on. ${ }^{36}$ These practices have their basis in the Qur'an. Ibn Khaldun also saw Sufism as part of the science of the Shari'a. That is, Sufism is a science that has a theological basis in Islam. It is impossible for this knowledge to be born and practiced without a solid foundation. Judging from the way of life of the Prophet SAW and his companions has indicated the practice of Sufism long before Islam developed rapidly. Ibn Khaldun relies on Sufism on the practice of living closer to God. From this, both Ibn Taimiyah and Ibn Khaldun confirm that Sufism has a solid theological basis. Otherwise, Muslims will sin and do useless work because they do not have a solid basis as a justification.

Discussions about häl also received attention from Ibn Taimiyah and Ibn Khaldun. Ibn Taimiyah has the view that it is wrong if the terms maqām and hāl in good Sufism are faith, kindness, taqwā, honesty, fairness, ihsan, patience, gratitude, tawakkal, fear, hope, love, obedience, doing to parents, and keeping promises. Thoose are the term that comes from Sufism. But the term is found in the Qur'an and Hadith. ${ }^{37}$ The meaning is that the concepts of the term Sufism must be based on the Qur'an. If it is not based on the Qur'an, then it is erroneous and wrong. Preferably, the practice of Sufism that is

35 Ibn Khaldūn, Muqaddimah al-' Allämah Ibn Khaldūn (Beirūt: al-Mathba'ah al-Adabìyah, 1900), pp. 468-69.

36 Taimiyah, Fiqh Al-Tashawnuf, pp. 12-14.

37 Ibn Taimiyah mentions many of these Sufism terms by linking them to the Qur'an and the hadiths of the Prophet SAW. Taimiyah, Figh Al-Tashawnuf, p. 24. 
taught and practiced among Muslims must be based on the Qur'an and hadith.

Ibn Taimiyah and Ibn Khaldun also highlight the practice of Sufism throughout the early history of Islam until their time. Ibn Taimiyah considers that the practice of Sufism based on the word abl al-shuffah and the word showf can be justified. The justification in terms of terminology is simplicity (faqir) and staying away from the world (zubūd). ${ }^{38}$ Next, Ibn Khaldun noticed this as it came to him. The practice of living a simple Sufism and staying away from the world is carried to get closer to Allah SWT. A Sufi or salik, who follows a certain path or way of life must do and go through various stages in order to arrive at the highest degree. Ibn Taimiyah and Ibn Khaldun agree that the highest degree for a salik is taqwā. Because the best of people those who are pious. ${ }^{39}$

Sufism, which started from the orientation of morals and character, shifted its paradigm to theoretical matters in its development. It is clear that there are terms such as ittihäd, Hulūl, Wabdat al-Wujüd, and others. At least, these three terms have colored the thought of Sufism in the body of Muslims. Ibn Taimiyah strongly criticized the notion of Wabdat al-Wujūd Ibn 'Arabī which states that all that exists in nature and humans, is united with God (manunggal). This will lead to the understanding of pantheism, which is clearly shirk and contrary to Islam's teachings. Ibn Taimiyah saw that the argument stated by Ibn 'Arab was a wrong argument and had to be rectified. ${ }^{40}$ This criticism is launched because it has led the people to a wrong and even misguided understanding, which therefore equates God and nature.

${ }^{38}$ Ibn Taimiyah emphasized that the life of a servant ('ábid) is not appropriate in luxury and indulgence. Instead, we have to imitate the life attitude of the Prophet SAW, which is simple and always stays away from the world. Taimiyah, Fiqh Al-Tashawnuf, pp. 27, 69-72.

${ }^{39}$ QS. Al-Hujurāt [49]: 13.

40 Abulhasan 'Alī Nadvī, Shaikh Al-Islam Ibn Taimiyah: Life and Achievements (Leicester: UK Islamic Academy, 2005).
Ibn Khaldun said the same thing in the Muqaddimah. Sufism became a separate discipline in Islam after this paradigm shift. Previously, Sufism was only a science that developed as well as the knowledge of the Qur'an, interpretation, hadith, and fiqh. Even just a living practice. ${ }^{41}$ Ibn Khaldun in several teachings of Sufism quotes as Ibn Dakhān's statement that the understanding of Sufism's teachings with the nuances of asceticism and syathabāt is a wrong thought, both on the concepts of ittibād, Hulül, and Wabdat al-Wujūd. According to Ibn Khaldun, such ideas will lead to the division of the ummah because they have different mystical visions. On the one hand, the jurists as law-holding authorities refuse, on the other hand, the spiritualists accept with great joy. He also added that such an understanding of philosophical Sufism is not suitable for conveying and disseminating to the broader community. ${ }^{42}$ Rather it becomes consumption for certain people as taught by Imam al-Ghazālī.

The discussion of Sufism in the perspective of Ibn Taimiyah and Ibn Khaldun at least gives the meaning that Sufism can be accepted as a science in Islam. Ibn Taimiyah discusses Sufism in the perspective of fundamental Islamic teachings. He criticizes Sufism at the theoretical level, namely philosophical Sufism, which according to him has erred in understanding Sufism and certain concepts, both in the terminology of the Qur'an and others. It also straightens out that the concepts of Sufism can be explored in the Qur'an and hadith. Because from both the theoretical and practical teachings of Islam were delivered. Meanwhile, Ibn Khaldun discusses Sufism in the frame of systematization of knowledge. Ibn Khaldun shows Sufism as a science that was born later in Islamic civilization and also experienced significant developments. Some of the concepts of philosophical Sufism did not escape criticism

\footnotetext{
${ }^{41}$ Khaldūn, p. 473.

42 Khaldūn, p. 474.
} 
by Ibn Khaldun by using the concept approach of well-known Islamic scholars. At least Ibn Khaldun's efforts in grouping the knowledge can give an idea of the importance and depth of the study of Sufism from ancient times to the present.

\section{SUFISM DISCOURCE BETWEEN IBN TAIMIYAH AND IBN KHALDUN}

The concept of Sufism as explained by Ibn Taimiyah and Ibn Khaldun has similarities and differences. The reason behind this thought is that both of them are basically not experts in Sufism, as are al-Qusyairī, al-Sulamī, al-Ghazālī, and other figures in the world of Sufism. Both are Islamic figures who are qualified in their respective fields. Ibn Taimiyah is known as a faqih, which means he understands the laws surrounding Islamic law so well that he is nicknamed Shaykh al-Islam. While Ibn Khaldun is known as an expert in Islamic history and sociologist who later became known as the Father of Sociologists. With such a background, it does not mean that the two of them did not study Sufism. However, both of them also studied Sufism as a scientific discipline in the midst of Muslims. Ibn Taimiyah looked at Sufism in the critical discipline of Islam with a scriptualistfundamentalist approach. Meanwhile, Ibn Khaldun sees Sufism in terms of the systematization of knowledge, which builds a rational-empirical civilization. ${ }^{43}$

As stated at the beginning of this research, Ibn Taimiyah and Ibn Khaldun have the spirit of reviewing the treasures of Islamic scholarship, not spared from it, namely Sufism. Both have the same perception that Sufism is a science that came later in Islam. Because it came later, the definitions made also varied. They both agree that the meaning of Sufism comes from the words shawf and suffah, which indicate the

43 Rahmat Effendi, 'Ilmu Pengetahuan Dan Pembagiannya Menurut Ibn Khaldun', TAJDID: Jurnal Ilmu Ushuluddin, $18.2 \quad$ (2019), $177-208$ <https://doi.org/10.30631/tjd.v18i2.99>. simplicity of a Sufi in his life. Both also have the same opinion in assessing Sufism that is carried out by someone who must go through certain maqām and get certain conditions (bāl) as well. The development of Sufism which is oriented towards moral improvement, adorning morals with commendable morals, avoiding despicable morals, and imitating the morals of the Prophet SAW and the good names of Allah SWT, is a good action. This shows that Sufism at the moralpractical level there is no difference between the two. In fact, Ibn Taimiyah quotes many verses of the Qur'an as legitimacy and affirmation of the concept of Sufism and its dimensions.

The difference between Ibn Taimiyah and Ibn Khaldun in Sufism is in terms of viewing this science from an epistemological perspective. Ibn Taimiyah criticizes a lot of philosophical Sufism in terms of ittihäd, Hulül, and Wahdat al-Wujüd in terms of Islamic fundamentalism. Ibn Taimiyah emphasized the importance of maintaining tawhìd as stated in the text of the verses of the Qur'an and hadith. The concepts of ittihäd, Hulül, and $W$ abdat al-Wujud indicate the existence of equality and unification between the Creator (alKhâliq) and the created (makhluq). The absence of difference between the two causes the sin of shirk. Then without realizing that such terms have exceeded the limits of humanity. ${ }^{44}$ The terms that exist in the world of Sufism, for Ibn Taimiyah are wrong terms and even heretical. He recommends that Muslims to stay away from these thoughts. ${ }^{45}$ On the contrary, Ibn Khaldun, viewed with a rationalist epistemology, thus emphasizing the scientific aspect in building arguments. At the end of the discussion of Sufism in the Muqaddimah, Ibn Khaldun argues that in the teachings of Sufism, there are things that can be learned and practiced by ordinary

${ }^{44}$ Muhammad Abu Zahrah, Ibn Taymiyah: Hayatubu wa 'Asharabu -Ara'abu wa Fiqhubu (Kairo: Dar al-Fikr al'Arabi, 1991), pp. 278-79.

45 The thought of Ibn al-'Arabi so that it is known as wabdat al-wujüd which was popularized by Ibn Taimiyah. Lihat Masood Ali Khan and S. Ram, Encyclopaedia of Sufism (India: Anmol Publications, 2003). 
people, and some can only be understood by certain people (khawas). Ibn Khaldun gives this emphasis in order to provide a comprehensive view of Sufism for Muslims.

Their thinking shows that Sufism needs to be reconstructed and straightened out among the people. They were reconstructed in the form of re-elaboration based on explicit arguments (sharih), then straightened out in the sense of explaining to the people comprehensively that in Sufism, there are teachings that are controversial if studied without an accurate explanation. Ibn Taimiyah emphasized the importance of having knowledge and doing good deeds based on religious law, namely the Qur'an and hadith. For him, knowledge is not practiced is a sin. While doing good deeds without knowledge is misguided. ${ }^{46}$ Sufism concepts that are built and practiced must be based on the Shari'a. Muslims cannot practice something without a foundation. This will later lead to the case of heresy. On the other hand, Ibn Khaldun stated that Sufism is part of the naqli science. ${ }^{47}$ Although it was born as a new discipline of knowledge after the death of the Prophet SAW, this knowledge is essential for Muslims. Because Sufism is a practice of worship and asceticism, the reality of science must dwell in such an understanding. Ibn Khaldun confirmed that Sufism underwent a paradigmatic shift in the developmental phase, from 'amali and akblaqi Sufism to philosophical Sufism. Philosophical Sufism is a development of 'amal' Sufism. Ibn Khaldun also saw that this orientation changed the course of figh from exoteric to esoteric. In that sense, the work done is not only seen in the outer meaning but from the inner meaning as well. The necessary emphasis as quoted by Ibn Khaldun from Ibn alKhāthib is to stay away from Sufism mixed with misleading Shia teachings. Because as it is known that in the early phase until the development of

\footnotetext{
46 Taimiyah, Figh Al-Tashawnuf, p. 24.

47 Semih Ceyhan, Ibn Khaldun's Perception of Sufis and Sufism: The Discipline of "Tasawwuf" in "Umran", Asian Journal of Social Science, 36.3/4 (2008), 483-515.
}

the Shia there were many oddities and ugliness in it.

Observing the study of Sufism that has been carried out, it is true that Ibn Taimiyah and Ibn Khaldun make criticisms. Ibn Taimiyah sharply criticized the concept of philosophical Sufism which he claimed was wrong and heretical. Especially his criticism of the concept of wabdat al-wujüd Ibn al-'Arabi. Even so, it does not reject Sufism as conceived by Muslims. On the other hand, Ibn Taimiyah emphasized the importance of relying on the knowledge of Sufism to the Qur'an and hadith. ${ }^{48}$ Ibn Taimiyah's answer to Sufism is at least partially accepted and partially rejected. As for Ibn Khaldun, assessing Sufism as the development of naqliyah and spiritual knowledge in Islam. Ibn Khaldun did not really enter into the world of Sufism, because he did not find his criticism of the science of Sufism. What is stated by Ibn Khaldun in his Muqaddimah only explains the classification of knowledge in Islam. Ibn Khaldun describes the breadth and depth of the study of Sufism in order to show the intellectual treasures of Islam. ${ }^{49}$

The similarities and differences in the concept of Sufism by Ibn Taimiyah and Ibn Khaldun explain that both are not experts in Sufism. Even being a Sufi and a sälik is unheard of. Ibn Taimiyah assesses Sufism in his work Fiqh al-Tashawnuf in order to show the actual Sufism practiced by Muslims. Ibn Taimiyah also warned not to get too deep into the ascetic world because it will drown in matters of subhat and sin. Even because they are influenced by lust, they cannot distinguish between inspiration and the devil's whispers. Then cannot distinguish between auliy $\vec{a}^{\prime}$ al-rabmān and auliya $\bar{a}^{\prime}$ al-syayathin. Ibn Khaldun explained what he had learned from the concepts of Sufism that came to him. ${ }^{50}$ Ibn Khaldun gives

48 Muhammad Basyrul Muvid, Tipologi Aliran-Aliran Tasawnf (Yogyakarta: BILDUNG, 2019).

49 Zakaria Stafa, 'Ibnu Khaldun dan Ilmu Tasawuf Berdasarkan Kitab Shifa' al-Sa'il li Tahdhib al-Masa'il', in Falsafah Ibnu Khaldun (Kuala Lumpur: Institut Terjemahan \& Buku Malaysia Berhad, 2015).

50 Taimiyah, Fiqh Al-Tashawnuf, pp. 88-98. 
an illustration that Sufism can be practiced by Muslims. Through his Muqaddimah, Ibn Khaldun wanted to show and broadcast parts of Islamic teachings including Sufism as part of esoteric Islam. At least the Muqaddimah has explained Sufism and its teachings as well as possible.

Bringing together the two Sufism thoughts of Ibn Taimiyah and Ibn Khaldun is not an easy matter. There is a need for data in the form of reliable and well-established literature. At least this research provides an initial picture that Sufism in Islam has aspects that are easy to understand and do. On the other hand, there are also difficult to understand things and must be studied in depth. Ibn Taimiyah and Ibn Khaldun's study of Sufism did not come from Sufism experts. But as an observer who took part in explaining and straightening the study of Sufism in the midst of Muslims. It is normal if the study of something is also studied by people who are not experts. Even so, both of them show good faith in the study of Sufism and provide a new discourse for future research.

\section{CONCLUSION}

This research has attempted to reveal a comparative study of the concept of Sufism by Ibn Taimiyah and Ibn Khaldun. This study only talks at the level of initial Sufism theory and has not shown how deep the study of Sufism is at an advanced level (falsafi). Glancing at the comparison of the falsafi Sufism concepts of the two figures, it may not be answered in this study. Even just mentioning it in general and not or have not studied it specifically. On the other hand, this research has shown similarities and differences of opinion between the two figures above in terms of definitions, elements, dimensions, and schools of Sufism. However, this research does not enter into the realm of Sufism schools. Because basically the two figures are not from the Sufi circles. Likewise with this research, because the concern in this study is not talking about the sharpening of the concept but the comparison of views by the two figures.
The hope in the future is that there will be research that clearly and clearly examines the comparison of the concepts of Sufism by Ibn Taimiyah and Ibn Khaldun. Subsequent further studies, at least provide a clear explanation of the concept of Sufism agreed upon by the two figures, both from a theoretical and practical point of view. Even the development of Sufism in the form of tariqat which is also the focus of the study of the two figures in his works can also be raised. This shows readers and observers of Islamic studies that Sufism is a discipline within Islam. Sufism cannot be seen as a science that comes out of Islam just because it is a strange argument. Instead, it is a science that can be developed in the future and practiced in life.

\section{BIBLIOGRAPHY}

Aceh, Abu Bakar. Pengantar Sejarah Sufi \& Tasawnuf. Solo: Ramadhani, 1994.

'Ali, 'Isa 'Abdullah. "al-Falsafat wa al-Tashawwuf fi Fikr Hujjat al-Islam Abi Hamid alGhazali." DINIKA: Academic Journal of Islamic Studies 2, no. 2 (30 Agustus 2017): 247.

https://doi.org/10.22515/dinika.v2i2.826

Anșārī, M. Abdul Haq. "Ibn Taymiyyah and Sufism." Islamic Studies 24, no. 1 (1985): 112.

Azhim, Sa'id 'Abd al-'. Manbaj Syaikh al-Islam Ibn Taimiyah : al-Tajdidiy al-Salafiy wa Da'wat alIshlabiyyat. Iskandariyah: Dar al-Iman, t.t.

Bagir, Haidar. Buku Saku Tasawuf. Mizan, 2006. . Mengenal Tasawuf. Jakarta: Noura Books, 2019.

Casewit, Stephen. "The Mystical Side of the Muqaddimah: Ibn Khaldun's View of Sufism." Islamic Quarterly 29, no. 3 (1 Januari https://search.proquest.com/docview/13 04268338?pqorigsite $=$ gscholar\&fromopenview $=$ true.

Ceyhan, Semih. 'Ibn Khaldun's Perception of Sufis and Sufism: The Discipline of 
"Tasawwuf in 'Umran." Asian Journal of Social Science 36, no. 3/4 (2008): 483-515.

Corbin, Henry. History of Islamic Pbilosophy. London and New York: Routledge, 2014.

Effendi, Rahmat. "Ilmu Pengetahuan Dan Pembagiannya Menurut Ibn Khaldun." TAJDID: Jurnal Ilmu Ushuluddin 18, no. 2 (2019): $177-208$. https://doi.org/10.30631/tjd.v18i2.99.

Hammud, Kamil. Dirasat fi Tarikh al-Falsafat al'Arabiyyat. Cet. 1. Beirut: Dar al-Fikr alLibnani, 1990.

Homerin, Th. E. "Ibn Taimìya's al-Șufiyah wa-alFuqaāà." Arabica 32, no. 2 (1985): 21944.

Huda, Sokhi. Tasawuf Kultural: Fenomena Shalawat Wahidiyah. Yogyakarta: LKiS Yogyakarta, 2008.

Ibn Taimiyah. Abl al-Shuffah: Majmu' Kitab wa Muallifat Syaikh al-Islam Ibn Taimiyah. Tanta: Dar al-Mahabbat li al-Turats, 1990. http://archive.org/details/Ibn_Taymiyah

Irwin, Robert. Ibn Khaldun: An Intellectual Biography. Princeton \& Oxford: Princeton University Press, 2019.

Khaldun, Ibn. Muqaddimah al-'Allamah Ibn Khaldun. Beirut: al-Mathba'ah alAdabīyah, 1900 . http://archive.org/details/muqaddimatal alla008800.

Khan, Masood Ali, dan S. Ram. Encyclopedia of Sufism. India: Anmol Publications, 2003.

Khan, Wahiduddin. Kritik Terbadap Ilmu Fiqih Tasawuf Dan Ilmu Kalam, judul asli Tajdid 'Ulum al-Din, terj. Moh. Nurbakim. Jakarta: Gema Insani Press, 1994.

Kholil, Abdul Munim. "Jejak Metodologis AntiSufi; Analisis Kritis Pemikiran Sufisme Ibnu Taymiyah." Reflektika 12, no. 1 (26 Oktober 2017): 20-37-37. https://doi.org/10.28944/reflektika.v13i1 70 .

Knysh, Alexander. Islamic Mysticism: A Short History. Leiden and Boston: Brill, 2010.
http://archive.org/details/IslamicMystici sm.

Ma'arif, Ahmad Syafi'i. Ibn Khaldun dalam Pandangan Penulis Barat dan Timur. Yogyakarta: Gema Insani, 1996.

Madjid, Nurcholish. Kaki Langit Peradaban Islam. Jakarta: DIAN RAKYAT dan PARAMADINA, 2009.

Marzouqi, Hassan. "Tariqa Islam: Layers of Authentication." Doha: Arab Center for Research \& Policy Studies, 2013. http://www.jstor.org/stable/resrep12704

Muvid, Muhammad Basyrul. Tipologi Aliran-Aliran Tasawuf. Yogyakarta: BILDUNG, 2019.

Nadvī, Abul Hasan 'Alī. Shaikh al-Islam Ibn Taimiyah: Life and Achievements. Leicester: UK Islamic Academy, 2005.

Nasr, Seyyed Hossein. "Sufism and Spirituality in Persia." Dalam Islamic Spirituality: Manifestations. New York: The Crossroad Publishing Company, 1997. http://archive.org/details/IslamicSpiritua lityManifestations.

. Tasawnf Dulu dan Sekarang, judul asli Living Sufism, terj. Abdul Hadi WM. Yogyakarta: IRCiSoD, 2020.

Nasution, Harun. Islam Ditinjau dari Berbagai Aspeknya. Vol. 2. Jakarta: Universitas Indonesia Press, 2015.

Nata, Abuddin. Studi Islam Komprehensif. Jakarta: Prenada Media, 2015.

Ni'am, Syamsun. "The Debate of Orthodox Sufism and Philosophical Sufism: The Study of Maqāmāt in the Sirāj al-Ṭālibīn of Shaykh Ihsān Jampes." Al-Jami'ab: Journal of Islamic Studies 58, no. 1 (1 Juli 2020): $1-34$. https://doi.org/10.14421/ajis.2020.581.1 -34 .

Noer, Kautsar Azhari. "Mukadimah." Dalam Warisan Agung Tasawnf: Mengenal Karya Besar Para Sufi. Jakarta: Sadra Press, 2015.

Nurdin, Eep Sofwana. Pengantar Ilmu Tasawuf. Bandung: Aslan Grafika Solution, 2020. 
Ozer, Yumna. Ibn Khaldun on Sufism: Remedy for the Questioner in Search of Answers. Cambridge: The Islamic Texts Society, 2017. http://archive.org/details/IbnKhaldunO nSufism.

Rahman, Fazlur. Islam. Chicago and London: University of Chicago Press, 2020.

Riyadi, Abdul Kadir. "Tasawuf Antara Penafsiran Normatif Dan Sosiologis Dalam Pemikiran Ibn Khald $₫$ «n.” ISLAMICA: Jurnal Studi Keislaman 12, no. 1 (4 September 2017): 80-166. https://doi.org/10.15642/islamica.2017.1 2.1.80-166.

Schimmel, Annemarie. Mystical Dimensions of Islam. Chapel Hill: The University of North Carolina Press, 1975. http://archive.org/details/mysticaldimen sionsofislam_201912.

Seyyed Hossein Nasr. Islamic Art \& Spirituality. New York: State University of New York Press, 1987. http://archive.org/details/islamicartspirit 00nasr.

Siroj, Said Aqil. Tasawnf Sebagai Kritik Sosial: Mengedepankan Islam Sebagai Inspirasi, Bukan Aspirasi. Bandung: Mizan Pustaka, 2006.

Stafa, Zakaria. "Ibnu Khaldun dan Ilmu Tasawuf Berdasarkan Kitab Shifa' al-Sa'il li Tahdhib al-Masa'il." Dalam Falsafah Ibnu Khaldun. Kuala Lumpur: Institut Terjemahan \& Buku Malaysia Berhad, 2015.

Taimiyah, Ibn. Fiqh al-Tashawnuf. Beirut: Dar alFikr al-'Arabi, 1993.

Istiqamah: Akidah, Ibadah, \& Tasawuf. Jakarta: Pustaka Al-Kautsar, 2016.

Wathoni, Lalu Muhammad Nurul. Akblak Tasawnf: Menyelami Kesucian Diri. Lombok: Forum Pemuda Aswaja, 2020.

Zahara, Muhammad Afiq. Pintu Tasawnf: Eksplorasi Singkat Terbadap Terminalterminal Sufi (Maqam Sufi). Yogyakarta: Penerbit Pacu Media, 2017.

Zahrah, Muhammad Abu. Ibn Taymiyab: Hayatubu wa 'Asharabu -Ara'abu wa Fiqbubu. Kairo:
Dar al-Fikr al-'Arabi, 1991. http://archive.org/details/IbnTaymiyah.

Zar, Sirajuddin. "Relevansi Tasawuf di Era Modern." Mumtaæ: Jurnal Studi Al-Quran dan Keislaman 2, no. 1 (2018): 121-32. https://doi.org/10.36671/mumtaz.v2i1.2 2.

Zuhri, H. Nalar Kalam Pertengahan. Yogyakarta: FA Press, 2015. 